\title{
Earnings Management Around Initial Public Offerings: Borsa Istanbul Application
}

\author{
Ömer Faruk GÜLEÇ \\ Hacettepe University \\ Faculty of Economics and \\ Administrative Science, \\ Business Administration \\ Department, Beytepe Campus \\ Ankara, Turkey \\ omerfarukgulec@gmail.com
}

\author{
Hüseyin TEMIZ \\ Hacettepe University \\ Faculty of Economics and \\ Administrative Science, \\ Business Administration \\ Department, Beytepe Campus \\ Ankara, Turkey \\ huseyintemiz1@hotmail.com
}

\author{
Semra KARACAER \\ Hacettepe University \\ Faculty of Economics and \\ Administrative Science, \\ Business Administration \\ Department, Beytepe Campus \\ Ankara, Turkey \\ semra@hacettepe.edu.tr
}

\begin{abstract}
This paper studies the presence of earnings management in initial public offerings (IPOs) of Turkish firms. The sample consists of 30 Turkish firms that went public in the years 2011 to 2015 on the Borsa Istanbul. Since there is no market-determined price for IPO share before they are sold to market participants by issuers and underwriters, increasing the attractiveness of an IPO share will be related the degree of earnings management before going public. Therefore this paper aims to find whether IPO issuers make discretionary accruals in their financial statements in order to affect the IPO share price before, during and after going public. According to the results, discretionary accruals level is the highest in the IPO year which is expected as in the other studies and there is statistically significant difference between different periods.
\end{abstract}

Keywords: Earnings Management, Initial Public Offerings, Discretionary Acrruals, Borsa Istanbul

\section{Introduction}

The initial public offerings which is one of the strategies to increase funds through selling the stocks in an organized capital market are heavily studied in accounting and finance literature, particularly the subjects of underpricing and price performance. Yet, earnings management in IPOs or any increasing or decreasing discretionary accrual behaviors for newly public firms is still unanswered question for the Turkish markets.

Earnings management is a well analyzed phenomenon in accounting literature. First pioneering empirical research in this field conducted in the middle of the 80's. Healy (1985) investigated the effects of bonus schemes on accounting choices and found strong evidence that managers change the accounting choices to get more bonus. Jones (1991) examined firms whether they exercise earnings management during International Trade Committee (ITC) investigation. Jones found that firms use discretionary accruals 
to get import guarantee. The key element of the earnings management is to alter provided information in the financial statements.

Earnings management is a well-studied concept discussed and developed by many researchers since 1980. The most cited and reached a consensus definition of earnings management expressed by Wahlen is as follows;

"Earnings management occurs when managers use judgement in financial reporting and in structuring transactions to alter financial reports to either mislead some stakeholder about the underlying economic performance of the company, or to influence contractual outcomes that depend on reported accounting numbers." (Healy \& Wahlen, 1999)

It is clear from the definition that earnings management is related to the judgement of altering financial information to achieve desired results. Studies in this context have generally investigated the underlying reasons, results and incentives of earnings management. The potentials of earnings management incentives are categorized in two main groups. The first group of earnings management motivating factors is managers' own personal purposes. For instance, managers may want to maximize their compensation, maintain job security and get promotion. The second group is related to company interests. According to this view, earnings management activities might be done to maximize share price and firm value and to minimize the probability of bankruptcy and to avoid violation restrictive debt covenant.

Earnings management before, during and after IPO period is also well documented in prior research, especially with the long performance of IPO. Initial Public Offering is a very specific span that a firm experiences huge amount of sales of shares to the investors. Going public is a milestone for a company to access capital and decrease the cost of funding for new investments and growth opportunities (Lin \& Tian, 2012).Yet, prior studies display when companies decide to go public, share prices fluctuates upward on the first day due to the fact of IPO underpricing. Theories explaining IPO underpricing state that information asymmetry plays an essential role to equalize the asymmetric informed parties in this process. Accounting conservatism is necessary to increase the quality of financial information and diminish the managers' interventions to effect profitability when greater information asymmetry exists (Lin \& Tian, 2012).

During the initial public offering, issuers and underwriters have specific and private information about the company's potential future benefits and threats. Managers know the investment decision, risk profiles or future cash flows. On the other hand, investors only have prospectus containing general information about the company and last 3 years audited financial statements. In order to decrease the information asymmetry between managers and investors, prospectuses may aid the potential investors what price should be for the IPO share.

Since the association between audited financial information and IPO offering price, issuers and underwriters are willing to exercise increasing earnings management to receive much proceeds from the offerings. There are generally high uncertainties about the newly public firm. Huge information asymmetries between the issuer and the investors and lack of reliable independent sources of information about the firm make the issues difficult for investors to judge the appropriateness of that IPO firm. 
If firms want to receive more proceeds before selling the shares in the market, latest financial statements of newly public firm will contain high and positive accruals. In addition to that Lockup agreements is another issue which is a voluntary contract between the pre-IPO shareholders and underwriter to prevent to sell the shares in the market generally for 180 days after IPO (Ertimur, Sletten, Sunder, \& Weber, 2015). In order to capture selling incentives after the Lockup expiration date by pre-IPO shareholders, strategic earnings management might be a good way to decorate the financial statements.

The fact that about firms going public borrow potential income from the future and use it in their latest financial statement before going public. Therefore, in the short run, there might be a difference between accruals and cash flows. Since the sum of a firm's income over all years must equal the sum of its cash flows in the long run, there will be no difference between accruals and cash flows.

Prior studies have identified an association between opportunistic earnings management and poor long run performance of initial public offerings in the post issuance period. The implications of earnings management for 3 years IPO stock performance handled by (Teoh, Welch, \& Wong, 1998). They demonstrated that firms with substantially high accruals in the IPO year ends up with relatively poor stock performance subsequent three years. After all either for the managerial incentives or the need more proceeds from going public are main motivations for opportunistic earnings management. This situation leads to fluctuations in the prices of IPO shares and investors experience less profit from the shares for the post IPO period especially in three years.

\section{Initial Public Offerings in Turkey}

There are numerous motivations to issue new shares and become a public company. Undoubtedly, issuing new shares is one of the vital financial strategy to meet the any financial needs. In order to raise enough capital to beat the targets and make investments, companies are eager to take place in an organized capital market and receive more proceeds. In addition, owing to become a public company, firms will have the chance more credibility, global reputation, institutionalization and issue seasoned equity offerings. All of the reasons mentioned above lead the Turkish firms open to the market and get benefits of becoming part of it. Financial liberalization have played an important role for promoting the banking and financial system during 1980 in Turkey (Aktas, Karan, \& Aydogan, 2003). Establishment of Borsa Istanbul in 1986 and Capital Markets Board in 1982 are significant steps to implement organized and regulated market. While there were only 287 listed companies at the end of 2000 with the $\$ 70$ billion market capitalization, it has climbed up to 535 listed companies with \$ 622 billion market capitalization in 2015. Even though there are certain disclosure and profit requirements before and after going public, number of IPOs and proceeds from selling the stocks increase except for the local or global crisis years. Number of IPOs and proceeds from IPOs and capital increase information are given in table 1 and table 2 respectively. 


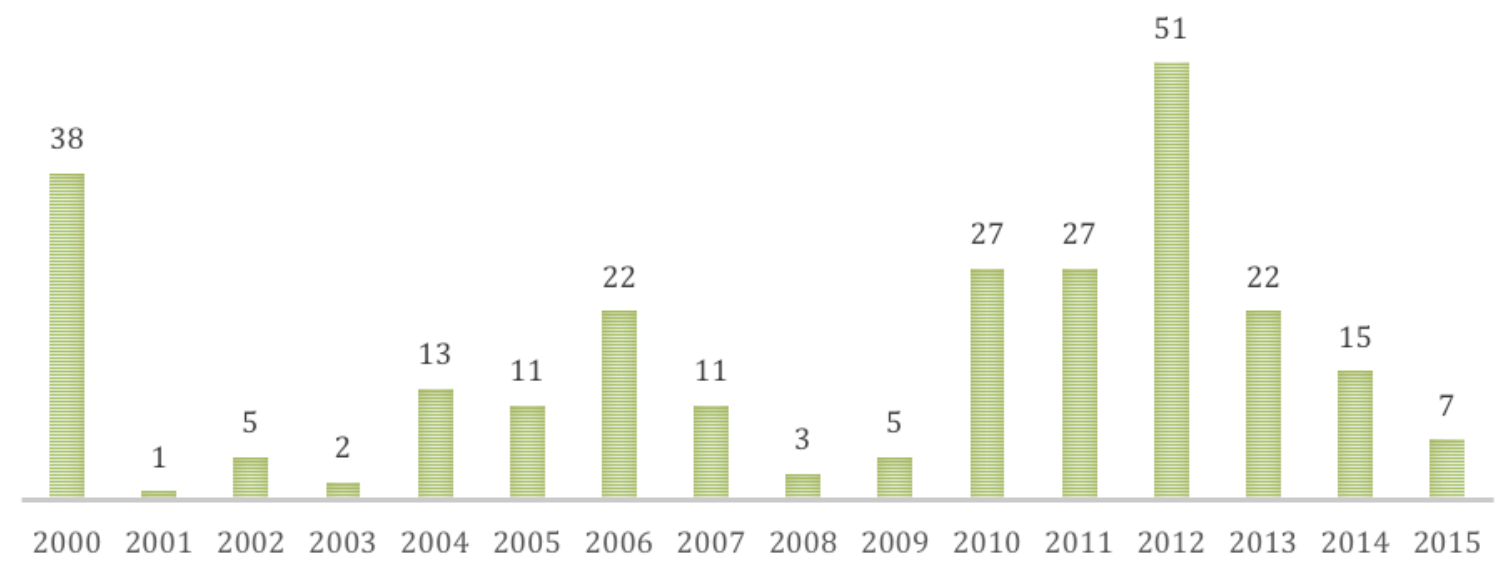

Figure 1: Number of IPOs

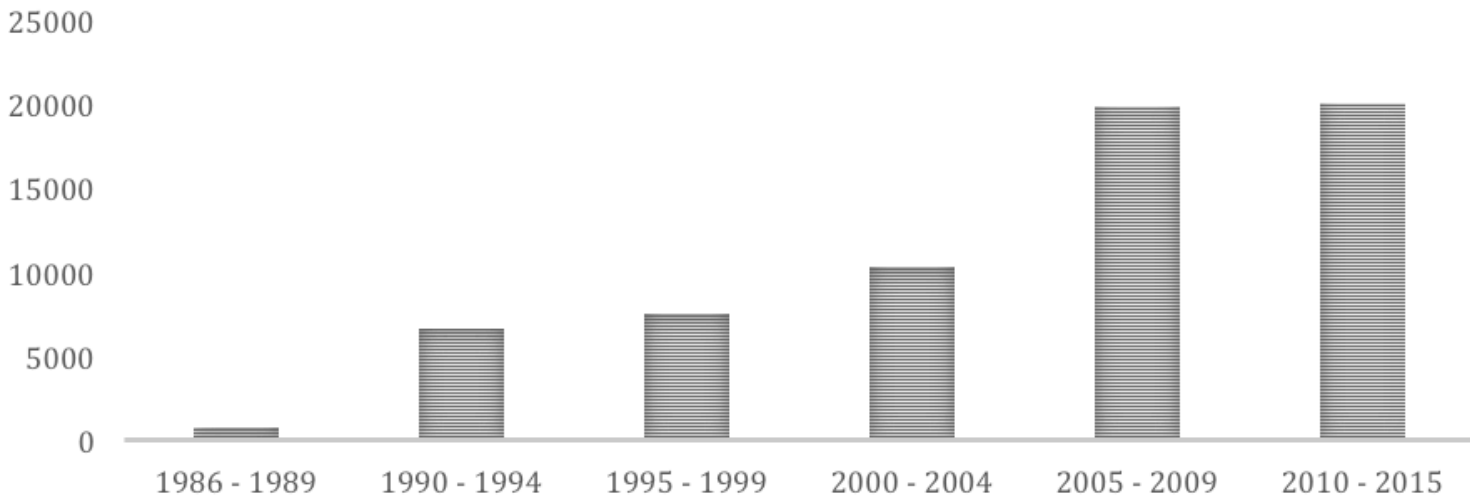

Figure 2 IPOs and capital increase through right issues volume (in million \$) Source: Borsa Istanbul website

\section{Literature Review}

Aharony, Lin and Loeb (1993) investigated whether issuers and underwriters manipulate earnings during the periods that firms going public through relying on Healy and DeAngelo approach. They studied on 229 USA industrial firms between the years 1985 - 1987. Their results suggested that small firms and firms with high financial leverage exercise more manipulating activities. In addition, earnings management is also related with the reputation of underwriters and auditors when going public.

Friedlan (1994) is one of the best studies that enlightened the association between income increasing activities of IPO firms and their performances with the 277 IPO firms. They used DeAngelo model modifying to estimate accruals to verify their hypotheses that issuers exercise earnings management to increase their welfare. Their studies especially highlights when IPO firms publish their first interim financial statements after going public, income increasing discretionary accruals are the highest 
compared to annual financial statement. If firms do not publish interim financial statements, annual statement which is most current display accounting discretion.

Neill, Pourciau, and Schaefer (1995) studied the association between accounting method choice and pricing of IPO firms with 505 companies. They supported their hypothesis and come up that greater underpricing arises from high income increasing accounting methods choices.

Teoh, Welch, et al. (1998) examined the long run performance of IPOs with the 1526 firms between 1975 and 1984. According to their results, three - year aftermarket stock return is \%20 less than aggressive periods of IPOs. They compared the IPO firms and nonissuers and concluded that discretionary current accruals which is a significant signal for earnings management is relatively higher. Teoh, Wong, and Rao (1998) also found positive accruals around IPO and negative abnormal accruals in the long run with the 8.199 IPO firms between the years 1980 - 1990 in the United States. When firms going public, their returns on shares are not only higher than industry peers but also higher than subsequent three years. They examined accounting method choices of the IPO firms additionally and displayed that depreciation methods and uncollectible accounts receivables are main items for opportunistic earnings management.

Roosenboom, van der Goot and Mertens (2003) analyzed 64 Dutch IPOs and they showed that the first year as a public company is the highest discretionary current accruals year comparing to the following years or previous years. They also supported the poor long run performance of IPOs such as many prior researches.

DuCharme, Malatesta, and Sefcik (2001) study indicates that firms' abnormal accruals before going public are positively related to initial proceeds. Therefore they receive a significant negative relationship between the level of abnormal accruals and post-performance of IPO firms. They analyzed 171 manufacturing IPO firms during the years 1982 to 1987 using different versions of the modified Jones model to estimate total and working capital accruals.

Gioielli and De Carvalho (2008) studied the role of venture capitalists for the four different periods of IPO. During the pre-IPO, IPO, lock-up period and post lock-up period, they divide their samples as venture-backed and non-venture-backed to indicate that income increasing activities only occur in the IPO period. They added that venturebacked IPOs exercises less earnings inflation activities compared to the non-venturebacked IPO firms for the four different phases.

Brau and Johnson (2009) gives another perspective to IPO studies through analyzing third-party certifiers. For 20 years period with 3900 IPO firms display negative and significant correlation between increasing earnings patters and prestigious of auditors, underwriters, attorneys and venture capitalists. According to their results, existence of prestigious third-party certifiers he mitigate the accruals management in IPO firms.

Iqbal, Espenlaub and Strong (2009) examined the long run operating and stock performance of $181 \mathrm{UK}$ IPO firms. Operating performance are measured through the ratio of net earnings and beginning period total assets, return on sales and the ratio of cash flow from operations beginning period total assets. According to the operating performance of IPO firms, they outperform their industry peers for the pre-IPO period and top performance occur in the IPO year. 
Lee and Masulis (2011) also search for an answer of the relation between investment banks' and venture capitalist' reputation. They concluded that prestigious investment banks and prestigious venture capitalists are complementary substitutes to mitigate the effects of earnings management activities.

Lin and Tian (2012) presents the negative association between accounting conservatism and underpricing of initial public offerings especially when information asymmetry is high in the Chinese stock market between the years 2001 and 2009.

Chiraz and Anis (2013) find no evidence to verify the relation initial proceeds and discretionary current accruals in 139 French IPO firms 1999 to 2007. However, they also concluded that first year for the firms as a public company is the highest period for earnings inflation.

Shen, Coakley and Instefjord (2014) empirically examined 506 Chinese IPO firms during the years 1998 - 2003 through developing a parsimonious pricing model. They demonstrate the association between earnings management and aftermarket price and offer price and they receive the same results about the poor long run performance of IPOs.

Miloud (2014) surveyed French firms that went public between the years 1995 and 2008 to find the incentives of managers and underwriters to deal with earnings management activities. They sum up that French IPOs manage their sales to reach a targeted objectives.

Shamszadeh and Bakhtiari (2015) investigated 47 IPO companies at Tehran Stock Exchange between the years 2000 and 2009. Even though they could not find any evidence for income increasing activities in the IPO year, they supported the hypothesis that pre-IPO period is the period IPO firms make earnings inflation.

Ertimur et al. (2015) divide the periods into IPO period and lockup expiration. They studied quarterly rather than annually to determine the effects of abnormal accruals. They stress on selling incentives of managers specifically on lockup period.

Papers empirically studying on initial public offerings in Turkey mainly concentrates on short or long term performance of shares and underpricing anomalies on Borsa Istanbul. Kiymaz (2000) analyzed 163 IPO firms between the years 1990 - 1996 and concluded that Turkish IPOs are underpriced \%13, 1 on average. Size or reputation of issuer, ownership structure and macroeconomic conditions of markets are essential determinants of underpricing. Aktas et al. (2003) is another study to display short term performance of 95 IPOs between the years $1997-2000$. They determine 9 features that are related with IPO performance and used different models to forecast the short term performance.

To the best knowledge, Yükseltürk (2006) is the only study that gives insights about earnings management for Turkish IPOs through calculating discretionary accruals to examine whether managers of IPOs alter their accounting policies before, during or after going public. In the study, 95 IPOs selected between the years $1994-2001$ and concluded that companies increase their discretionary accruals before going public. In the IPO year, discretionary accruals reaches the maximum level and for the following year it falls to the levels before the IPO periods. This study shows that Turkish IPOs 
deal with income increasing activities to make the shares more popular and attractive especially in the IPO year.

\section{Common Accrual Methods in Empirical Research}

In order to understand the earnings management activities, accrual concept should be well understood. Sloan (1996) defines accruals as the change in non - cash working capital less depreciation expense. In essence, any occurred accounting event can be defined as accrual. However, in general term, in order to call any event as an accrual, cash flow related to this transaction should not be realized such ass ales on credit, stocks bought on credit or depreciation expenses. Accrual basis accounting method differs from cash basis accounting for accepting income and expenses in different times (King, Lembke, \& Smith, 1997).

Measurement of accruals mainly includes two methods called balance sheet and cash flow statement methods which suggest different calculations. According to the balance sheet method and cash flow statement method for calculating accruals given below respectively;

Total Accruals $=[\Delta$ Current Assets $-\Delta$ Cash $]-[\Delta$ Short Term Liabilities $-\Delta$ Short Term Portion of Long Term Liabilities - $\Delta$ Income Tax Provision] - Depreciation Expenses (Jones, 1991).

Total Accruals = Income before Tax - Cash from Operations (Dechow, Kothari, \& Watts, 1998)

Many studies in earnings management literature claims that cash flow statement is superior to balance sheet method particularly when examining firms have acquisition, merger and unsustainable operations (Hribar \& Collins, 2002). Thus, in order to predict the accruals accurately, many accrual prediction models developed or modified from many academicians and some of those models that is commonly used is presented below chronologically.

\subsection{Healy Model (1985)}

Healy (1985) concentrates on the relationship between executive's bonus plans and manipulation of earnings to maximize their welfare and so as to analyze, estimation and event periods are determined. On the purpose of calculating discretionary accruals depending upon executives' behavior, Healy uses average total accruals for each firm in estimation period.

$\mathrm{NA}_{\mathrm{t}}=1 / \mathrm{n} \sum \mathrm{e}\left(\mathrm{TA}_{\mathrm{e}} / \mathrm{A}_{\mathrm{e}-1}\right)$

$\mathrm{NA}_{\mathrm{t}}=$ Nondiscretionary Accruals Deflated with Total Assets in Period $\mathrm{t}$

$\mathrm{n}=$ Number of Years in Estimation Period

$\mathrm{e}=$ Number of Years Belong to Estimation Period $(\mathrm{t}-\mathrm{n}, \mathrm{t}-\mathrm{n}+1, \ldots \mathrm{t})$

$\mathrm{A}_{\mathrm{e}-1}=$ Total Assets Belong to Previous Year from Each Year in Estimation Period

\subsection{De Angelo Model (1986)}

DeAngelo (1986) investigates the firms' deliberate actions to decrease share prices through using accruals when the management buyout occurs. In other words, firms decrease their share prices with the help of accruals to buy them back with a low 
price and negative discretionary accruals are the indication of this operation. There is no estimation period in Deangelo method and to calculate the accruals, total assets value in previous year is used as deflator. She assumes that nondiscretionary accruals in period $t$ will be equal to total accruals in period t- 1 and states that change in total accruals arises from discretionary accruals.

$\mathrm{NA}_{\mathrm{t}}=\mathrm{TA}_{\mathrm{t}-1} / \mathrm{A}_{\mathrm{t}-2}$

$\mathrm{NA}_{\mathrm{t}}=$ Nondiscretionary Accruals in Period $\mathrm{t}$

$\mathrm{TA}_{\mathrm{t}-1}=$ Total Accruals in Period $\mathrm{t}-1$

$A_{t-2}=$ Total Assets in Period $t-2$

\subsection{Jones Model (1991)}

Jones (1991) investigates whether firms manipulates their earnings to benefit from U.S. International Trade Commission's actions. Import relief operations which are tariff increases and quota reductions requires profitability that lead firms to explicit use of accounting numbers. Accruals are again such a good tool to manage income increasing activities therefore this study focus on the detection of earnings management for profitability. She expresses that accruals are the function of depreciations which is the component of changes in income and gross property, plant and equipment. Jones model also deflate the variables such as in the other studies with the total assets values in previous year.

$\mathrm{NA}_{\mathrm{i}, \mathrm{t}}=\alpha_{0 \mathrm{i}}\left(1 / \mathrm{A}_{\mathrm{i}, \mathrm{t}-1}\right)+\alpha_{1 \mathrm{i}}\left(\Delta \mathrm{REV}_{\mathrm{i}, \mathrm{t}} / \mathrm{A}_{\mathrm{i}, \mathrm{t}-1}\right)+\alpha_{2} \mathrm{i}\left(\mathrm{PPE}_{\mathrm{i}, \mathrm{t}} / \mathrm{A}_{\mathrm{i}, \mathrm{t}-1}\right)$

$\mathrm{NA}_{\mathrm{i}, \mathrm{t}}=$ Nondiscretionary Accruals in Period $\mathrm{t}$ for Firm $\mathrm{i}$

$\Delta \mathrm{REV}_{\mathrm{i}, \mathrm{t}}=$ Revenue Change in Period t for Firm i $\left(\mathrm{REV}_{\mathrm{t}}-\mathrm{REV}_{\mathrm{t}-1}\right)$

$\mathrm{PPE}_{\mathrm{i}, \mathrm{t}}=$ Gross Property, Plant and Equipment in Period $\mathrm{t}$ for Firm $\mathrm{i}$

$\mathrm{A}_{\mathrm{i}, \mathrm{t}-1}=$ Total Assets Value in Period t-1 for Firm $\mathrm{i}$

$\alpha_{0 \mathrm{i}}, \alpha_{1 \mathrm{i}}, \alpha_{2 \mathrm{i}}=$ Parameters for firms

Jones (1991) states that nondiscretionary accruals are related with the growth of revenues and gross property, plant and equipment and supposes that sales and plant, property and equipment can't be changed through management activities. Residual values of regression model given below is used with intent to determine discretionary accruals in Jones model.

$\mathrm{TA}_{\mathrm{i}, \mathrm{t}} / \mathrm{A}_{\mathrm{it}-1}=\beta_{0 \mathrm{i}}\left(1 / \mathrm{A}_{\mathrm{i}, \mathrm{t}-1}\right)+\beta_{1 \mathrm{i}}\left(\Delta \mathrm{REV}^{\mathrm{i}, \mathrm{t}} / \mathrm{A}_{\mathrm{i}, \mathrm{t}-1}\right)+\beta_{2 \mathrm{i}}\left(\mathrm{PPE}_{\mathrm{i}, \mathrm{t}} / \mathrm{A}_{\mathrm{i}, \mathrm{t}-1}\right)+\dot{\varepsilon}_{\mathrm{i}, \mathrm{t}}$

$\mathrm{TA}_{\mathrm{i}, \mathrm{t}}=$ Total Accruals in Period $\mathrm{t}$ for Firm $\mathrm{i}$

$\beta_{0 \mathrm{i}}, \beta_{1 \mathrm{i}}, \beta_{2 \mathrm{i}}=\alpha_{0 \mathrm{i}}, \alpha_{1 \mathrm{i}}, \alpha_{2 \mathrm{i}}$ values predicted using ordinary least square method

$\dot{\varepsilon}^{\prime} i_{\mathrm{t}}=$ Discretionary Accruals in Period $\mathrm{t}$ for Firm I

\subsection{Modified Jones Model (1995)}

While Jones (1991) model offers that firms don't do earnings management through using accruals, Dechow, Sloan, and Sweeney (1995) on the other hand argues 
that earnings management is possible with usage of sales and adds calculating discretionary accruals in Jones model has missing points. They customize the model through subtracting the change in trade receivable from the change in revenue. According to Dechow et al. (1995), with the help of this correction, accruals arise from sales on credit is separated from the increase on sales will improve the power of test.

$$
\mathrm{TA}_{\mathrm{i}, \mathrm{t}} / \mathrm{A}_{\mathrm{it}-1}=\beta_{0 \mathrm{i}}\left(1 / \mathrm{A}_{\mathrm{i}, \mathrm{t}-1}\right)+\beta_{1 i}\left[\left(\Delta \mathrm{REV}_{\mathrm{i}, \mathrm{t}}-\Delta \mathrm{REC}_{\mathrm{i}, \mathrm{t}}\right) / \mathrm{A}_{\mathrm{i}, \mathrm{t}-1}\right]+\beta_{2 \mathrm{i}}\left(\mathrm{PPE}_{\mathrm{i}, \mathrm{t}} / \mathrm{A}_{\mathrm{i}, \mathrm{t}-1}\right)+\dot{\varepsilon} \mathrm{i}_{, \mathrm{t}}
$$

$\Delta \mathrm{REC}_{\mathrm{i}, \mathrm{t}}=$ Change in Trade Receivables in Period t for Firm i $\left(\mathrm{REC}_{\mathrm{t}}-\mathrm{REC}_{\mathrm{t}-1}\right)$

\section{Research Design}

\subsection{Sample Selection}

The main purpose of this study is to examine whether propensity of earnings management activities of Turkish IPOs are associated with the period in which they publish their financial statements. Thus, we analyzed the years between 2010 and 2015 in Borsa Istanbul in order to detect increasing or decreasing discretionary accruals behavior. Firstly we determined all IPO companies that went public during these years and the reason we chose 2010 as the starting point is related to number of IPOs which are relatively few before 2010. After subtracting the financial companies and the firms whose data are out of reach from the sample, we finally obtain 30 IPOs between these years. The IPO companies and the other companies in 5 sectors are given in table 1 .

Table 1 IPO Sample Selection

\begin{tabular}{|l|c|c|c|c|c|}
\hline & Basic Materials & Industrial & Energy & Technology & Total \\
\hline Companies in the sectors & 69 & 48 & 8 & 15 & 140 \\
\hline Ipos in the sectors & 5 & 19 & 3 & 3 & 30 \\
\hline
\end{tabular}

\subsection{Hypothesis}

Since the main purpose of firms is to increase the shareholders welfare, share prices and profitability of firms become more significant and apparent particularly in initial public offerings. In order to get more proceeds from the IPO process, firms may exercise increasing discretionary accruals activities. In many IPO studies this causal link is studied with the long run share return performance of IPOs. Time periods are significant to establish a relationship between the process of IPO and earnings management activities.

$\mathrm{T}_{-1}$

(Before going public)

$$
\mathrm{T}_{0}
$$

(During going public)
$\mathrm{T}_{1}$

(After going public)

Investors and creditors stress on the last audited financial statements for the accurate assessment in which the firms before going public. $\mathrm{T}_{-1}$ period displays the last audited financial statements' discretionary accruals measured through modified Jones model. Thus, our first hypothesis is;

$H_{1}$ : Firms exercise increasing (positive) discretionary accruals before going public in $T_{-1}$ period. 
$\mathrm{T}_{0}$ period shows the time when firms become a public company and the discretionary accruals are calculated from the first financial statements of open to the public. These financial statements are attributed particular emphasis due to the lock up period for the managers. Because the managers are supposed to wait at least 6 months to sell their shares, share prices should be in a high level that they attain more gains when they want to sell. Therefore our second hypothesis is;

$\mathrm{H}_{2}$ : Firms exercise more increasing (positive) discretionary accruals when they become a public company in T0 period.

$\mathrm{T}_{1}$ period demonstrates the time when company completes the full year as a public company and the discretionary accruals are measured from the financial statements after the lock up period. Therefore managers generally do not deal with the increasing discretionary accruals exercises. In the long term, positive accruals are supposed to be negative in order to reach zero point. Since the sum of a firm's income over all years must equal the sum of its cash flows in the long run, there will be no difference between accruals and cash flows. Thus our third hypothesis is;

$H_{3}$ : Firms exercise decreasing (negative) discretionary accruals after the lock - up period in $T 1$ period.

In other IPO studies such as Friedlan (1994) or Yükseltürk (2006), discretionary accrual values are compared with $\mathrm{T}$ test to prove that there is statistically significant difference between the different periods. In this study, we also compared the values with the $\mathrm{T}$ test and we expected significant differences. Our fourth hypothesis is;

$\mathrm{H}_{4}$ : There is statistically significant difference between the discretionary values of IPO firms in different periods.

\subsection{Research Findings}

When we examine the results of discretionary accruals, as expected, $\mathrm{T}_{0}$ period is the time in which the IPO firms exercises the highest accruals activities in order to effect the share prices and profitability of firms positively. As mentioned in Friedlan (1994) $T_{0}$ period is an essential time to influence the investors through publishing solid financial statement with better financial results. Increasing discretionary accrual activities will drive up the profitability of the company and in the end managers are able to sell their shares after the lock-up period easily. Therefore, it may be commented that receiving the highest accruals in $\mathrm{T}_{0}$ period leads us to evaluate the company particularly in managerial concerns. Managers' stock options, bonus plans or any perquisites directs them to manipulate the financial results for their own purposes.

Since issuing new shares as opening to public is the significant portion of capital structure decisions and options, getting more capital from the sales of shares during the IPO process is vital for the firms (Teoh, Welch, \& Wong, 1998). $\mathrm{T}_{-1}$ period results proves that managers put emphasis on increasing accruals to gain more proceeds for IPO process. As mentioned above for $\mathrm{T}_{0}$ period, still managers' personal aims may motivate them to impress the financial statements. Being a profitable company is a prerequisite for becoming an IPO, for this reason, increasing discretionary accrual activities may be applied in $\mathrm{T}_{-1}$ period. Thereby, two hypothesis are accepted according to the results. 
On the other hand, hypothesis 3 related to the T1 period is not accepted due to the positive accrual result. Even though discretionary accruals are lessening and there is a significant difference between the other periods and $\mathrm{T} 1$ period, it needs to be negative to prove that after becoming a public company, motivations for increasing discretionary accrual exercises will slow down. However, the graph below shows the general pattern and it conforms to the literature. In the long run, increasing discretionary accrual activities should be compensated decreasing discretionary accrual activities to equalize the cash flow and income differences.

Table 2 IPOs Discretionary Accruals Results

\begin{tabular}{|c|c|c|c|}
\hline & $\mathbf{T}_{\mathbf{- 1}}$ & $\mathbf{T}_{\mathbf{0}}$ & $\mathbf{T}_{\mathbf{1}}$ \\
\hline Average DA & 0,0318 & 0,1183 & 0,0133 \\
\hline Median DA & 0,0314 & 0,0870 & 0,0297 \\
\hline \multirow{3}{*}{ T Statistics } & $\mathrm{T}_{-1}-\mathrm{T}_{0}$ & $0,0990^{*}$ & $* 0,10$ \\
\cline { 2 - 4 } & $\mathrm{T}_{0}-\mathrm{T}_{1}$ & $0,016^{* *}$ & $* * 0,05$ \\
\cline { 2 - 4 } & $\mathrm{T}_{-1}-\mathrm{T}_{1}$ & 0,6590 & $* * * 0,01$ \\
\hline
\end{tabular}

$\mathrm{T}_{0}$ period is crucial comparing the previous and later periods for the $\mathrm{T}$ test. There is a statistically significant difference between the $T_{0}-T_{1}$ and $T_{0}-T_{-1}$ periods as expected but there is no significant difference between $T_{-1}-T_{1}$ periods due to the fact that $\mathrm{T}_{1}$ period does not produce negative result as expected.

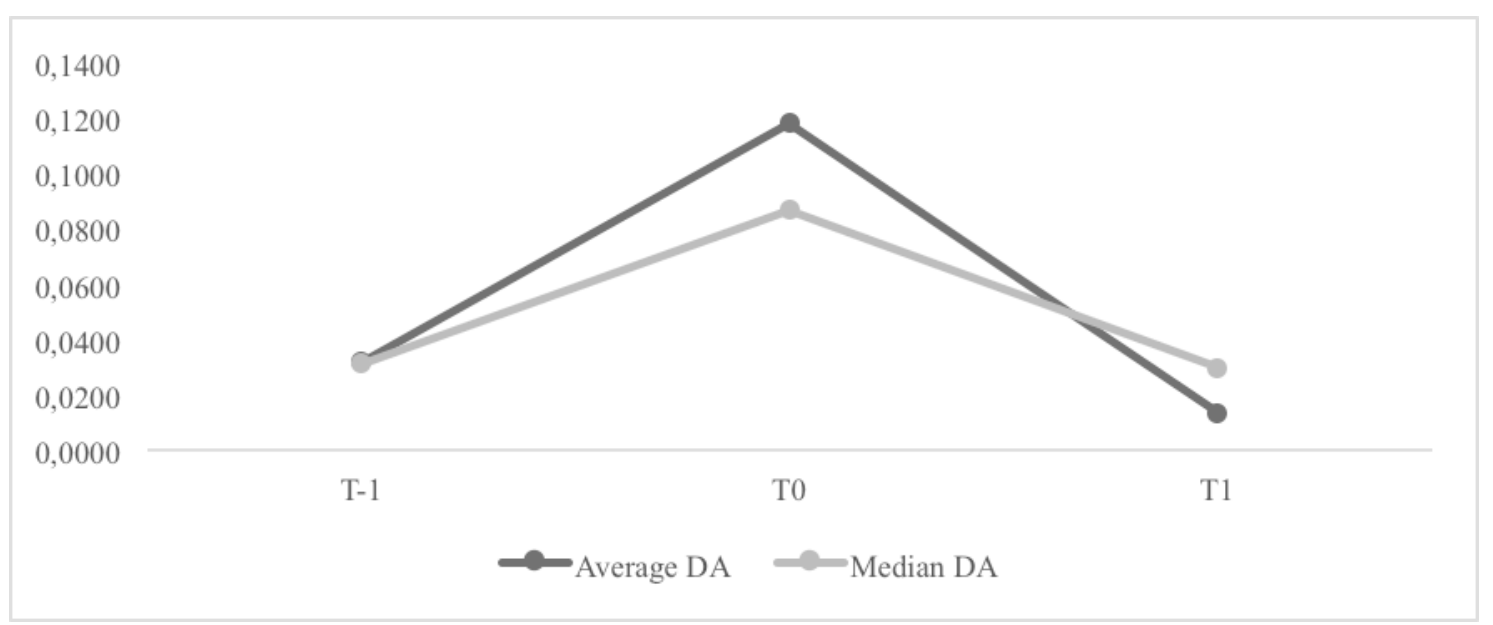

Figure 3: IPOs Discretionary Accruals

\subsection{Conclusion}

Earnings management is widely studied in accounting literature. Earnings management activities in IPO firms especially in emerging countries like Turkey is the main question that needs to be searched. Thus, we address the issue of increasing or decreasing accruals behavior in different periods of IPO firms elaborately.

Going public and becoming an open public company is a milestone decision for a company and investing in these companies is also another issue for any player in the market. Thus, this study will give insights to the third parties who consider investing or crediting to the companies that goes public. Many of studies generally concentrates on 
the long run share performance of IPO companies with different return calculations. However, analyzing the accrual behavior of initial public offerings will help to investors to assess the options and make accurate decisions.

Since the number of companies that went public is limited, the results may not be generalized but it is the only study that examines IPO firms recently in Turkey to the best knowledge. Future studies may concentrate on future share performance of IPO firms in the long run with different return measurements. In addition, nonissuers can be used as benchmark in order to prove IPO firms' increasing discretionary accruals behaviors. Besides, through examining interim periods and other emerging countries financial statements may have the chance to get comparative results.

\section{References}

Aharony, J., LIN, C. J., \& Loeb, M. P. (1993). Initial public offerings, accounting choices, and earnings management. Contemporary accounting research, 10(1), 61-81.

Aktas, R., Karan, M. B., \& Aydogan, K. (2003). Forecasting short run performance of initial public offerings in the Istanbul Stock Exchange. The Journal of Entrepreneurial Finance, 8(1), 1.

Brau, J. C., \& Johnson, P. M. (2009). Earnings management in IPOs: Post-engagement third-party mitigation or issuer signaling? Advances in Accounting, 25(2), 125135.

Chiraz, D., \& Anis, J. (2013). Earnings management and performance of French IPO companies. Journal of Accounting and Taxation, 5(1), 1.

DeAngelo, L. E. (1986). Accounting numbers as market valuation substitutes: A study of management buyouts of public stockholders. Accounting review, 400-420.

Dechow, P. M., Kothari, S. P., \& Watts, R. L. (1998). The relation between earnings and cash flows. Journal of accounting and Economics, 25(2), 133-168.

Dechow, P. M., Sloan, R. G., \& Sweeney, A. P. (1995). Detecting earnings management. Accounting review, 193-225.

DuCharme, L. L., Malatesta, P. H., \& Sefcik, S. E. (2001). Earnings management: IPO valuation and subsequent performance. Journal of Accounting, Auditing \& Finance, 16(4), 369-396.

Ertimur, Y., Sletten, E., Sunder, J., \& Weber, J. (2015). When and Why do IPO Firms Manage Earnings? Available at SSRN.

Friedlan, J. M. (1994). Accounting choices of issuers of initial public offerings. Contemporary accounting research, 11(1), 1-31.

Gioielli, S. P. O., \& De Carvalho, A. G. (2008). The dynamics of earnings management in IPOs and the role of venture capital. Paper presented at the XXX Meeting of the Brazilian Econometric Society.

Healy, P. M. (1985). The effect of bonus schemes on accounting decisions. Journal of accounting and Economics, 7(1), 85-107.

Healy, P. M., \& Wahlen, J. M. (1999). A review of the earnings management literature and its implications for standard setting. Accounting horizons, 13(4), 365-383. 
Hribar, P., \& Collins, D. W. (2002). Errors in estimating accruals: Implications for empirical research. Journal of accounting research, 40(1), 105-134.

Iqbal, A., Espenlaub, S., \& Strong, N. (2009). Earnings management around UK open offers. The European Journal of Finance, 15(1), 29-51.

Jones, J. J. (1991). Earnings management during import relief investigations. Journal of accounting research, 193-228.

King, T. E., Lembke, V. C., \& Smith, J. H. (1997). Financial accounting: a decisionmaking approach: J. Wiley.

Kiymaz, H. (2000). The initial and aftermarket performance of IPOs in an emerging market: evidence from Istanbul stock exchange. Journal of Multinational Financial Management, 10(2), 213-227.

Lee, G., \& Masulis, R. W. (2011). Do more reputable financial institutions reduce earnings management by IPO issuers? Journal of Corporate Finance, 17(4), 982-1000.

Lin, Z. J., \& Tian, Z. (2012). Accounting conservatism and IPO underpricing: China evidence. Journal of International Accounting, Auditing and Taxation, 21(2), 127-144.

Miloud, T. (2014). Earnings Management And Initial Public Offerings: An Empirical Analysis. Journal of Applied Business Research, 30(1), 117.

Neill, J. D., Pourciau, S. G., \& Schaefer, T. F. (1995). Accounting method choice and IPO valuation. Accounting horizons, 9(3), 68.

Roosenboom, P., van der Goot, T., \& Mertens, G. (2003). Earnings management and initial public offerings: Evidence from the Netherlands. The International Journal of Accounting, 38(3), 243-266.

Shamszadeh, B., \& Bakhtiari, A. (2015). Earnings Management and Initial Public Offerings (IPOs) at Tehran Stock Exchange (TSE). Mediterranean Journal of Social Sciences, 6(6 S6), 92.

Shen, Z., Coakley, J., \& Instefjord, N. (2014). Earnings management and IPO anomalies in China. Review of Quantitative Finance and Accounting, 42(1), 69-93.

Sloan, R. (1996). Do stock prices fully reflect information in accruals and cash flows about future earnings?(Digest summary). Accounting review, 71(3), 289-315.

Teoh, S. H., Welch, I., \& Wong, T. J. (1998). Earnings management and the long run market performance of initial public offerings. The Journal of Finance, 53(6), 1935-1974.

Teoh, S. H., Wong, T. J., \& Rao, G. R. (1998). Are accruals during initial public offerings opportunistic? Review of accounting studies, 3(1-2), 175-208.

Yükseltürk, O. (2006). İşletmelerde Kârı Yüksek Gösterme Yöntemleri ve Türkiye'de Hisse

Senetlerinin Halka Arzı Öncesi Kârı Yüksek Gösterme Eğilimleri. İstanbul University Unpublished Ph.D.. dissertation. 